Niam R Al-Saleem BDS, MSc ( Lec.)

\title{
Comparison of Lip Analyses in Skeletal Class I Normal Occlusion and Class II Divi- sion 1 Malocclusion
}

Dept of Pedod, Orthod, and Prev Dentistry

College of Dentistry, University of Mosul

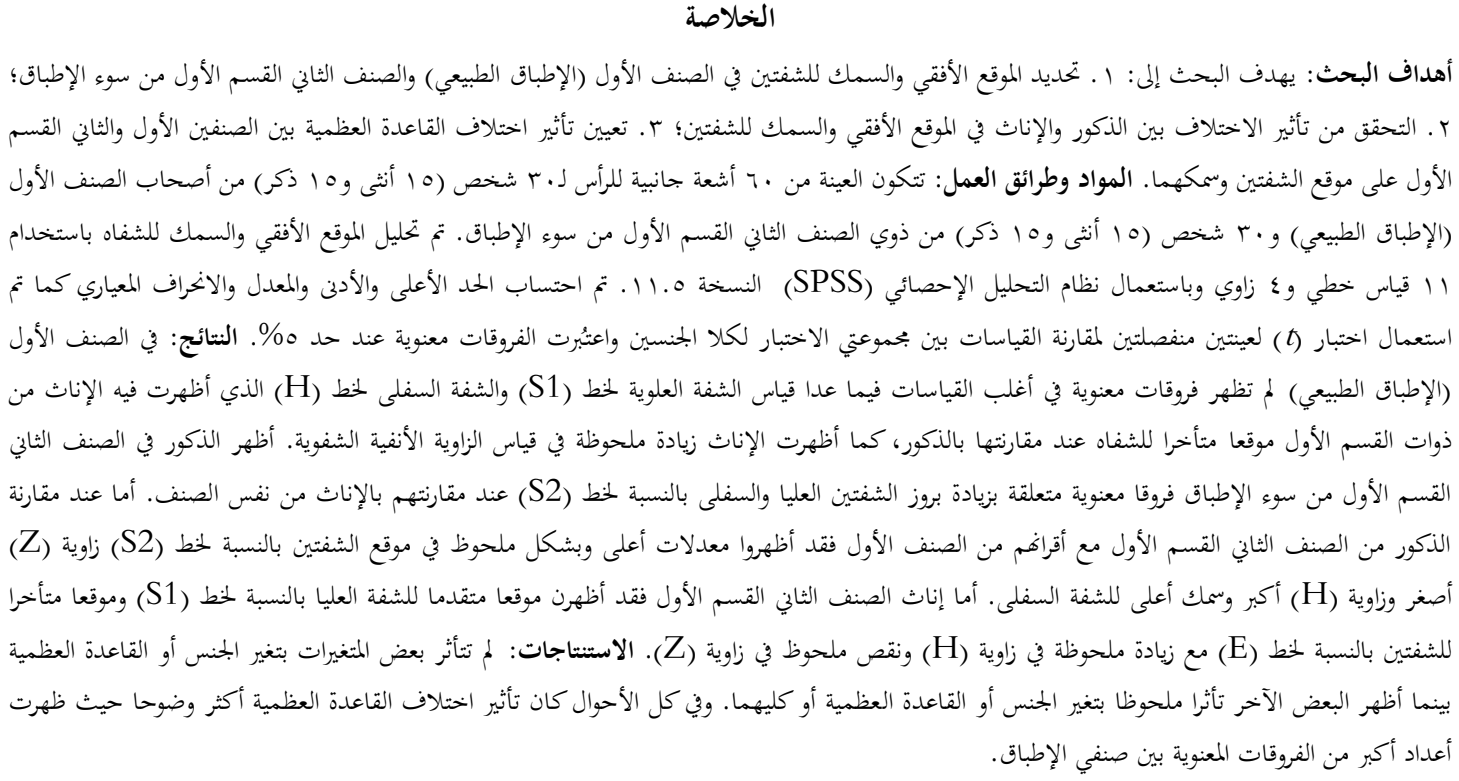

\section{ABSTRACT}

Aims: To 1. Assess the horizontal lip position and lip thickness in both Class I and Class II Division 1 subjects; 2. To investigate the effect of gender on the horizontal lip position and lip thickness; 3 . To identify the effect of skeletal differences on lip position and thickness. Materials and Methods: The sample consisted of 60 cephalometric radiographs of 30 dental and skeletal Class I subjects (15 males, 15 females) and 30 dental and skeletal Class II Division 1 subjects (15 males, 15 females). The horizontal lip position and thickness was analyzed using 11 linear and 4 angular measurements. Using SPSS software package (version 11.5), descriptive statistics and independent sample $t$-test were measured to compare between the two Classes and two genders. The differences were considered significant at $p \leq 0.05$. Results: In Class I no significant differences were noticed in most of the variables except in upper lip (Ls) to Steiner line and lower lip (Li) to Holdaway line where females showed more retruded position and larger nasolabial angle (NLA) when compared to males. In Class II Division 1 subjects, the upper and lower lips were significantly protrusive in males when compared with females in relation to Sushner line $\left(\mathrm{S}_{2}\right)$. Class II Division 1 males showed more protruded upper and lower lips in relation to $\mathrm{S}_{2}$ line, significantly smaller $\mathrm{Z}$ angle and higher $\mathrm{H}$ angle when compared with Class I males. Comparison between Class I and Class II Division 1 females showed a significantly higher value of upper lip in relation to Steiner line $\left(S_{1}\right)$, and significantly smaller upper and lower lips in relation to $\mathrm{E}$ line, smaller $\mathrm{Z}$ angle and larger $\mathrm{H}$ angle. Conclusions: Some of the variables were not affected neither by gender nor by skeletal base while other showed statistically significant differences following gender or skeletal Class or both. However, the effect of skeletal base difference was more obvious as higher number of significant differences were seen between the two Classes.

Key Words: Lip position, Soft tissue, Class II Division 1.

Al-Saleem NR. Comparison of Lip Analyses in Skeletal Class I Normal Occlusion and Class II Division 1 Malocclusion. Al-Rafidain Dent J. 2013; 13(2): 192-201.

Received: $8 / 5 / 2011$

Sent to Referees: $11 / 5 / 2011$

Accepted for Publication: 29/6/2011

\section{INTRODUCTION}

Harmonious facial esthetics and opti- mal functional occlusion have long been recognized as the most important goal of 
orthodontic treatment. ${ }^{(1,2)}$

The facial skeleton and the overlying soft tissue determine the facial harmony and balance. However, it is the structure of the overlying soft tissue and their relative proportions that provide the visual impact of the face. ${ }^{(3)}$

Soft tissue analysis and evaluation of the patient soft tissue profile plays an important role in orthodontic diagnosis, planning orthodontic treatment and orthognathic surgery to maximize function and esthetics. ${ }^{(4-6)}$

The success of orthodontic treatment is frequently related to the improvement gained in the patient facial appearance which includes the soft tissue profile. ${ }^{(7)}$ The quantitative analysis of the soft tissue facial profile measurements are necessary in all medical specialties that can change facial traits as it is an essential for diagnosis of dentofacial alteration and deformities. ${ }^{(8,9)}$

As facial appearance is a fundamental for communication and interaction with the environment and has become ever increasingly important during the last decade. Recently the field of orthodontics has experienced a paradigm shift to focus more on esthetics, with specific emphasis on soft tissues around the mouth. ${ }^{(10-12)}$

Many authors have studied the facial esthetics. ${ }^{(13-21)}$ Orthodontists have focused on the horizontal lip position as the most important feature in determining beauty. Several lines have been introduced to assess the antero-posterior position of the upper and lower lips and the esthetic quality of the profile. ${ }^{(22)}$

The aims of this study were: 1) To assess the horizontal lip position and lip thickness in both Class I and Class II Division 1 subjects; 2) To investigate the effect of gender on the horizontal lip position and lip thickness; and 3) To identify the effect of skeletal differences on lip position and thickness.

\section{MATERIALS AND METHODS}

The sample consisted of 60 cephalometric radiographs of 30 Class I (15 males and 15 females) dental and skeletal sub- jects with normal overbite $(0-4 \mathrm{~mm})$ and overjet $(0-4 \mathrm{~mm})$, full set of permanent teeth and ANB angle of $2 \pm 2$ degrees with no history of orthodontic treatment or orthognathic surgery; and 30 Class II Division 1 (15 males and 15 females) with increased overjet more than $5 \mathrm{~mm}$. The ANB angle $\geq 5.5^{\circ}$. Also they have no missing permanent teeth and no history of orthodontic treatment and orthognathic surgery. The sample age ranging from 1923 years with an average of 22.3 years.

The radiographs were obtained in Mosul University, Dentistry College, Department of Pedodontics, Orthodontics and Preventive Dentistry. The radiographs were traced and analyzed.

The horizontal lip position and thickness were analyzed using 11 linear and 4 angular measurements. The following reference lines were used and the position of the lips was recorded (+ve) when it was in front of the lines and (-ve) when located behind the lines (Figures 1 to 6 ):

1. E line: The line tangent from the tip of the nose to the soft tissue pogonion. This line was employed by Ricketts who stated that the upper and lower lips lie behind this line a mean distance of $2 \mathrm{~mm}$ and $4 \mathrm{~mm}$, respectively.

2. $S_{1}$ line: Employed by Steiner extending from the middle of the $\mathrm{S}$-shaped curve between the tip of the nose and the subnasale to the soft tissue pogonion. Steiner stated that the lips should touch the reference plane.

3. B line: Burstone drew this line from the soft tissue subhasale to soft tissue pogonion. The upper and lower lips were located anterior to this line a mean distance of $3.5 \mathrm{~mm}$ and $2.2 \mathrm{~mm}$, respectively.

4. $S_{2}$ line: Sushner developed this line from soft tissue nasion to soft tissue pogonion and the upper and lower lips were anterior to this line of about 6.7 to $8.8 \mathrm{~mm}$ in females and 7.8 to $10.3 \mathrm{~mm}$ in males.

5. $\mathrm{H}$ line: This line was developed by Holdaway as a tangent to the upper lip from soft tissue pogonion, and a modification of this line developed by Merrifield drawn from soft tissue pogonion to the most procumbent lip. 


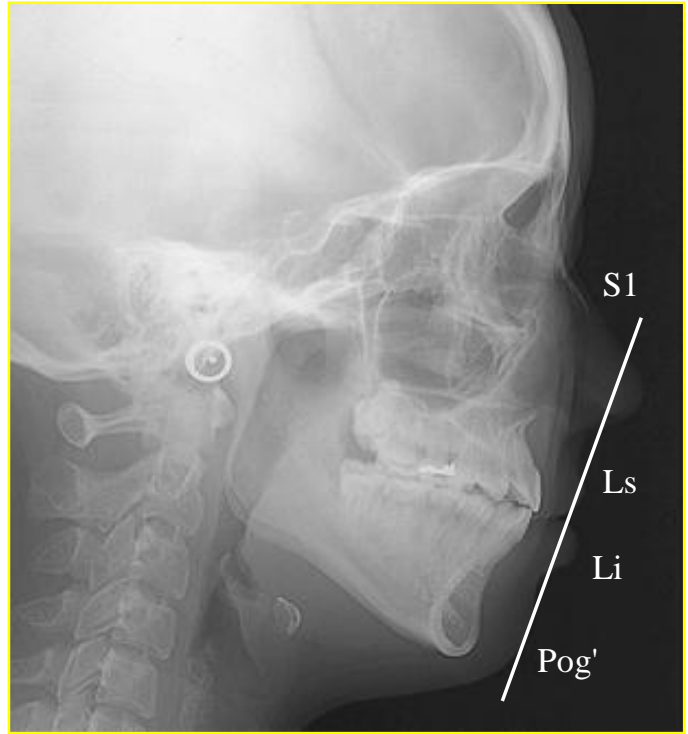

Figure (1): Steiner lip analysis; S1 from the middle of the $\mathrm{S}$-shaped curve of the nose to soft tissue pogonion; Ls:upper lip to S1 line; Li: lower lip to S1 line.

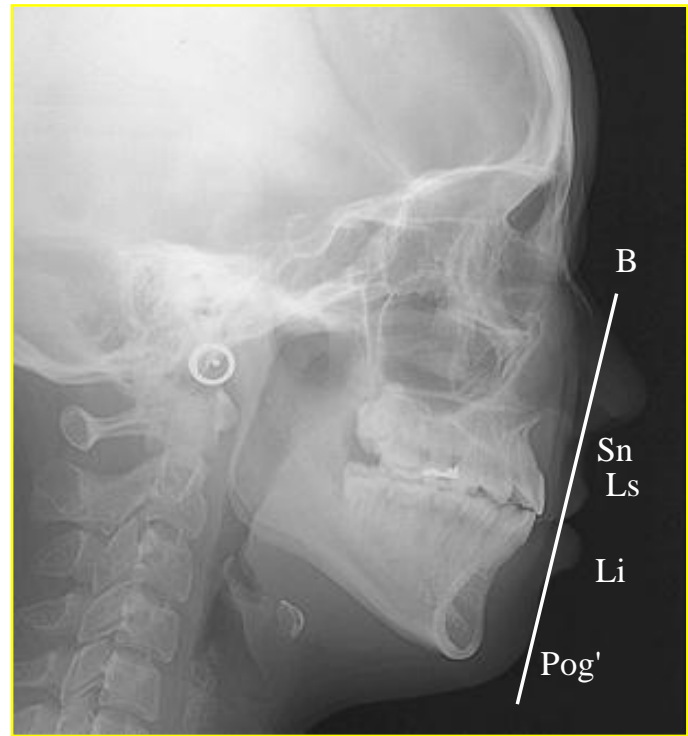

Figure (3): Burstone lip analysis; B from soft tissue subnasal to soft tissue pogonion; Ls: upper lip to B line; Li: lower lip to B line.

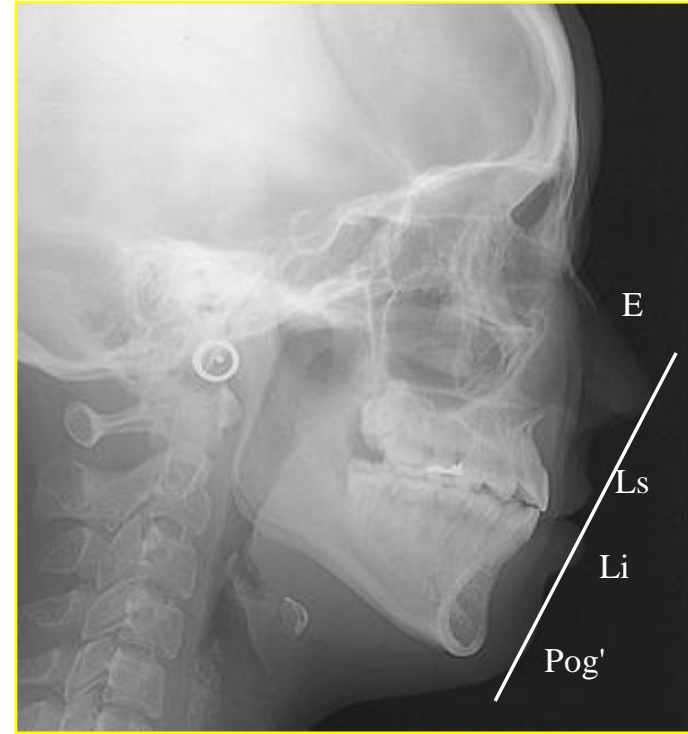

Figure (2): Ricketts lip analysis; E from tip of the nose to soft tissue pogonion; Ls: upper lip to E line; Li: lower lip to E line.

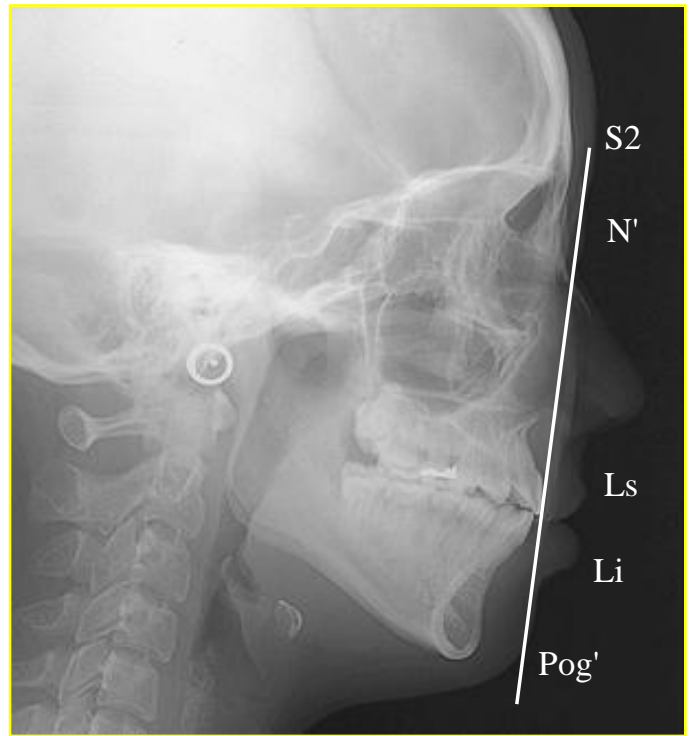

Figure (4): Sushner lip analysis; S2 from soft tissue nasion to soft tissue pogonion; Ls: upper lip to S2 line; Li: lower lip to S2 line. 


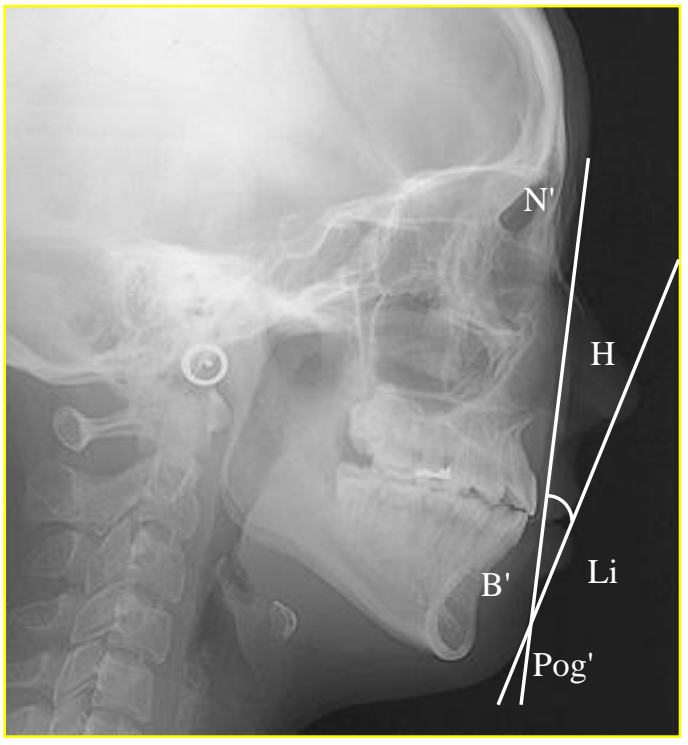

Figure (5): Holdaway lip analysis; H line tangent to upper lip from soft tissue pogonion; $\mathrm{H}$ angle between soft tissue nasion - soft tissue point $\mathrm{B}$ and $\mathrm{H}$ line; Li: lower lip to $\mathrm{H}$ line line.

The following measurements were employed (Figure 1 to 7 ):

1. Steiner Ls: The mm distance of the upper lip in relation to $S_{1}$ line.

2. Steiner Li: The mm distance of the lower lip in relation to $S_{1}$ line.

3. Ricketts Ls: Upper lip $\mathrm{mm}$ distance in relation to $\mathrm{E}$ line.

4. Ricketts Li: Lower lip $\mathrm{mm}$ distance in relation to $\mathrm{E}$ line.

5. Burstone Ls: Upper lip $\mathrm{mm}$ distance in relation to B line.

6. Burrstone Li: Lower lip $\mathrm{mm}$ distance in relation to B line.

7. Sushner Ls: Upper lip $\mathrm{mm}$ distance in relation to $S_{2}$ line.

8. Sushner Li: Lower lip $\mathrm{mm}$ distance in relation to $\mathrm{S}_{2}$ line.

9. Holdaway $\mathrm{H}$ : An angle between $\mathrm{H}$ line and nasion-point $\mathrm{B}$.

10. Holdaway Li: Lower lip mm distance in relation to $\mathrm{H}$ line.

11.Z angle: The angle between the Marrifield line and Frankfort horizontal.

12. Nasolabial angle: The angle between the

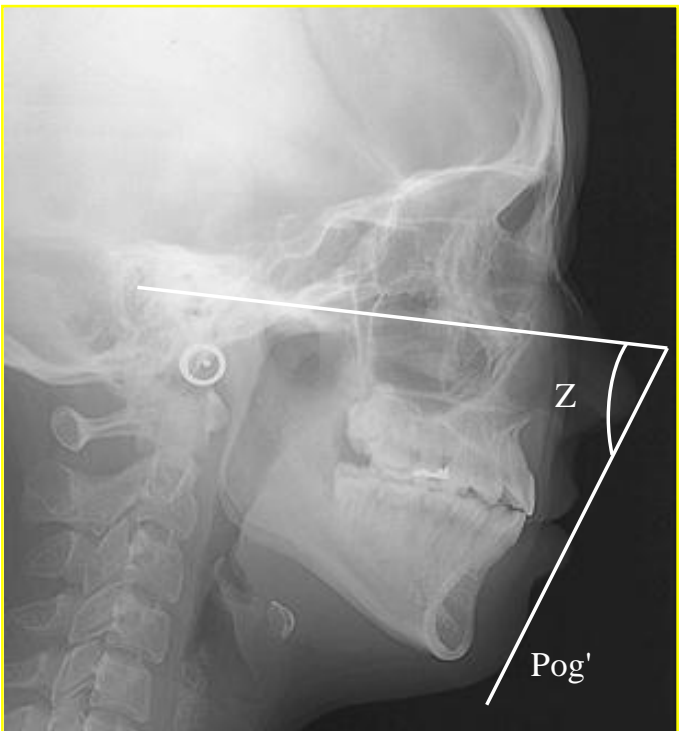

Figure (6): Merrifield lip analysis; $\mathrm{Z}$ angle between FH and a line from soft tissue pogonion to the most procumbent lip.

line tangent from the Sn to the lower border of the nose and the line from the Sn to the upper lip.

13.Labiomental angle: Formed by the intersection of a line drawn between the sulcus inferior and soft tissue chin and a line originated at the sulcus inferior tangent to the lower lip.

14.Upper lip thickness: The $\mathrm{mm}$ distance between the vermillion border of the upper lip and labial surface of the upper incisor.

15.Lower lip thickness: The $\mathrm{mm}$ distance between the vermillion border of the lower lip and labial surface of the lower incisor.

The data were analyzed using Statistical Package for Social Sciences (SPSS) software package (version 11.5). The minimum, maximum, mean and standard deviation were measured. Independent sample $t$-test were performed to compare the measurements between the two genders and the two classes. The differences were considered significant at $p \leq 0.05$. 


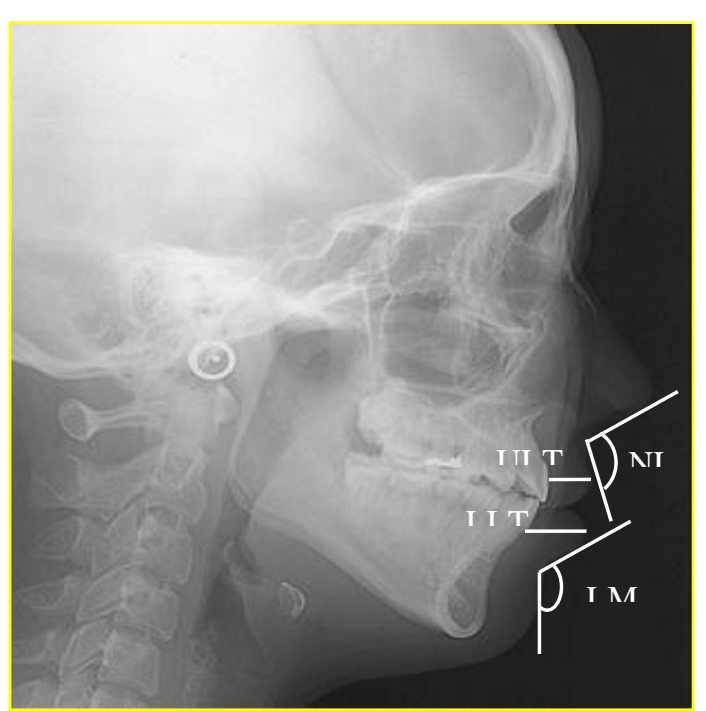

Figure (7): ULT: Upper lip thickness;LLT: lower lip thickness; NLA: nasolabial angle; LMA: labiomental angle.

\section{RESULTS}

Descriptive statistics including mean, minimum, maximum, standard deviation in addition to $t$-test and $p$-value for Class I males and females were shown in Table (1).

No significant differences were noticed in most of the variables except in Steiner Ls where females showed a more retruded position of the upper lip in relation to $S_{1}$ line.

The significantly retruded lower lip in females were noticed in relation to $\mathrm{H}$ line with a significantly larger NLA angle.

Table (1): Descriptive statistics and comparison between Class I males and females.

\begin{tabular}{|c|c|c|c|c|c|c|c|c|}
\hline Variable & No. & Gender & Mean & $\pm \mathrm{SD}$ & Min. & Max. & $t$-test & $p$-value \\
\hline \multirow{2}{*}{ Steiner Ls } & 15 & Males & 1.531 & 3.451 & -7 & 8.5 & \multirow{2}{*}{2.145} & \multirow{2}{*}{$0.040 *$} \\
\hline & 15 & Females & -0.546 & 1.761 & -5 & 1.75 & & \\
\hline \multirow{2}{*}{ Steiner Li } & 15 & Males & 1.053 & 3.861 & -6 & 7 & \multirow{2}{*}{1.085} & \multirow{2}{*}{0.286} \\
\hline & 15 & Females & -0.109 & 1.855 & -3 & 3.75 & & \\
\hline \multirow{2}{*}{ Ricketts Ls } & 15 & Males & -5.153 & 3.559 & -12 & 0.5 & \multirow{2}{*}{0.306} & \multirow{2}{*}{0.762} \\
\hline & 15 & Females & -5.640 & 2.010 & -10 & 20 & & \\
\hline \multirow{2}{*}{ Ricketts Li } & 15 & Males & -3.140 & 2.735 & -9 & 1 & \multirow{2}{*}{-1.139} & \multirow{2}{*}{0.264} \\
\hline & 15 & Females & -4.140 & 2.204 & -6 & -2.5 & & \\
\hline \multirow{2}{*}{ Burstone Ls } & 15 & Males & 3.890 & 2.491 & -2 & 9 & \multirow{2}{*}{1.227} & \multirow{2}{*}{0.229} \\
\hline & 15 & Females & 3.046 & 1.160 & -0.25 & 4.75 & & \\
\hline \multirow{2}{*}{ Burstone Li } & 15 & Males & 3.218 & 2.309 & -2.5 & 8 & \multirow{2}{*}{2.307} & \multirow{2}{*}{$0.028^{*}$} \\
\hline & 15 & Females & 1.578 & 1.166 & -1 & 5 & & \\
\hline \multirow{2}{*}{ Sushner Ls } & 15 & Males & 9.375 & 4.209 & 1 & 20 & \multirow{2}{*}{0.341} & \multirow{2}{*}{0.735} \\
\hline & 15 & Females & 8.890 & 3.815 & 0.25 & 14 & & \\
\hline \multirow{2}{*}{ Sushner Li } & 15 & Males & 7.468 & 2.969 & 0 & 12 & \multirow{2}{*}{0.434} & \multirow{2}{*}{0.668} \\
\hline & 15 & Females & 7.000 & 3.145 & 2 & 13 & & \\
\hline \multirow{2}{*}{ Holdaway Li } & 15 & Males & 1.333 & 1.588 & -1 & 4 & \multirow{2}{*}{-0.889} & \multirow{2}{*}{$0.022 *$} \\
\hline & 15 & Females & -0.133 & 1.726 & -3 & 2 & & \\
\hline \multirow{2}{*}{$\mathrm{H}^{\circ}$} & 15 & Males & 11.800 & 3.320 & 4 & 16 & \multirow{2}{*}{0.331} & 0.743 \\
\hline & 15 & Females & 11.366 & 3.838 & 8.5 & 18 & & 0.143 \\
\hline $7^{\circ}$ & 15 & Males & 74.656 & 6.262 & 65 & 87 & 2421 & 0381 \\
\hline & 15 & Females & 76.656 & 6.467 & 66 & 89 & 2.421 & 0.501 \\
\hline $\mathrm{NLA}^{\circ}$ & 15 & Males & 101.533 & 11.945 & 83 & 122 & -2285 & $0030 *$ \\
\hline & 15 & Females & 110.900 & 10.461 & 90 & 124 & $-2.20 \mathrm{~J}$ & 0.030 \\
\hline $\mathrm{LMA}^{\circ}$ & 15 & Males & 119.366 & 30.762 & 108 & 137 & -0.836 & 0.410 \\
\hline & 15 & Females & 126.633 & 30.693 & 89 & 143 & -0.030 & \\
\hline ULT & 15 & Males & 13.183 & 1.548 & 11 & 15 & 0.510 & 0.614 \\
\hline UL1 & 15 & Females & 12.766 & 2.757 & 9.5 & 16.5 & & \\
\hline LLT & 15 & Males & 16.000 & 1.463 & 11 & 19 & 1.107 & 0.278 \\
\hline & 15 & Females & 15.133 & 2.655 & 11 & 20.5 & 1.107 & \\
\hline
\end{tabular}

No: number; SD: standard deviation; Min.: Minimum; Max.: Maximum. * Significant difference existed at $p \leq 0.05$. 
Mean, minimum, maximum, standard deviation, $t$-test and $p$-value of Class II Division 1 males and females were demonstrated in Table (2).

The upper and lower lips were significantly protrusive in males than females in relation to $S_{2}$ line.

Table (3) described the mean, standard deviation, maximum, minimum, $\mathrm{t}$-test and $p$-value of Class I and Class II Division 1 males.

Class II Division 1 males showed a more protruded upper and lower lips in relation to $S_{2}$ line, significantly smaller $Z$ angle and higher $\mathrm{H}$ angle, and significantly higher lower lip thickness.

Table (2): Descriptive statistics and comparison between Class $\mathrm{II}_{1}$ males and females.

\begin{tabular}{|c|c|c|c|c|c|c|c|c|}
\hline Variable & No. & Gender & Mean & \pm SD & Min. & Max. & $t$-test & $p$-value \\
\hline \multirow{2}{*}{ Steiner Ls } & 15 & Males & 1.375 & 2.269 & -2 & 6 & \multirow{2}{*}{0.058} & \multirow{2}{*}{0.955} \\
\hline & 15 & Females & 1.328 & 2.237 & -4 & 6 & & \\
\hline \multirow{2}{*}{ Steiner Li } & 15 & Males & 2.218 & 2.988 & -5 & 7 & \multirow{2}{*}{1.170} & \multirow{2}{*}{0.251} \\
\hline & 15 & Females & 1.140 & 2.156 & -3 & 5.5 & & \\
\hline \multirow{2}{*}{ Ricketts Ls } & 15 & Males & -3.875 & 3.471 & -8 & 5.5 & \multirow{2}{*}{0.988} & \multirow{2}{*}{0.331} \\
\hline & 15 & Females & -2.937 & 1.537 & -5 & 0 & & \\
\hline \multirow{2}{*}{ Ricketts Li } & 15 & Males & -2.625 & 3.575 & -8 & 5 & \multirow{2}{*}{0.942} & \multirow{2}{*}{0.354} \\
\hline & 15 & Females & -1.718 & 1.425 & -4 & 1 & & \\
\hline \multirow{2}{*}{ Burstone Ls } & 15 & Males & 4.687 & 3.181 & 0 & 13 & \multirow{2}{*}{0.611} & \multirow{2}{*}{0.546} \\
\hline & 15 & Females & 3.093 & 2.237 & 2 & 10 & & \\
\hline \multirow{2}{*}{ Burstone Li } & 15 & Males & 4.125 & 3.626 & -2 & 10 & \multirow{2}{*}{0.089} & \multirow{2}{*}{0.930} \\
\hline & 15 & Females & 3.031 & 2.132 & 1 & 8 & & \\
\hline \multirow{2}{*}{ Sushner Ls } & 15 & Males & 15.012 & 5.186 & 8 & 23.7 & \multirow{2}{*}{3.239} & \multirow{2}{*}{$0.003^{*}$} \\
\hline & 15 & Females & 9.687 & 4.045 & 1 & 20 & & \\
\hline \multirow{2}{*}{ Sushner Li } & 15 & Males & 10.375 & 4.638 & 2.5 & 17 & \multirow{2}{*}{2.174} & \multirow{2}{*}{$0.038 *$} \\
\hline & 15 & Females & 7.743 & 3.096 & 0 & 12.5 & & \\
\hline \multirow{2}{*}{$\begin{array}{c}\text { Holdaway } \\
\text { Li }\end{array}$} & 15 & Males & 0.500 & 2.674 & -5 & 4 & \multirow{2}{*}{-0.392} & \multirow{2}{*}{0.698} \\
\hline & 15 & Females & 0.812 & 1.682 & -4 & 3 & & \\
\hline \multirow{2}{*}{$\mathbf{H}^{\circ}$} & 15 & Males & 17.866 & 4.517 & 10 & 25 & \multirow{2}{*}{0.192} & \\
\hline & 15 & Females & 17.593 & 3.352 & 12 & 22 & & 0.849 \\
\hline & 15 & Males & 60.875 & 10.136 & 47 & 76 & & \\
\hline $\mathbf{Z}^{\circ}$ & 15 & Females & 62.466 & 7.314 & 47 & 73 & 0 & 28 \\
\hline & 15 & Males & 104.000 & 16.505 & 88 & 130 & & \\
\hline $\mathbf{N L A}^{\circ}$ & 15 & Females & 104.562 & 12.527 & 75 & 127 & 07 & 0.915 \\
\hline & 15 & Males & 100.733 & 23.026 & 62 & 135 & & \\
\hline $\mathbf{L M A}^{\circ}$ & 15 & Females & 109.375 & 21.810 & 60 & 140 & -1.073 & 0.292 \\
\hline & 15 & Males & 12.800 & 2.284 & 9.5 & 10 & & \\
\hline ULT & 15 & Females & 12.031 & 3.775 & 8 & 19 & 0.665 & 0.511 \\
\hline & 15 & Males & 17.733 & 2.520 & 15.5 & 21 & & \\
\hline LLT & 15 & Females & 17.000 & 2.846 & 15.5 & 20 & 7 & 4 \\
\hline
\end{tabular}

No: number; SD: standard deviation; Min.: Minimum; Max.: Maximum. * Significant difference existed at $p \leq 0.05$. 
Table (3): Descriptive statistics and comparison between Class I and Class $\mathrm{II}_{1}$ males.

\begin{tabular}{|c|c|c|c|c|c|c|c|c|}
\hline Variable & No. & Class & Mean & $\pm \mathrm{SD}$ & Min. & Max. & $t$-test & $p$-value \\
\hline \multirow{2}{*}{ Steiner Ls } & 15 & I & 1.531 & 3.451 & -7 & 8 & \multirow{2}{*}{0.149} & \multirow{2}{*}{0.882} \\
\hline & 15 & $\mathrm{II}_{1}$ & 1.375 & 2.369 & -2 & 6 & & \\
\hline \multirow{2}{*}{ Steiner Li } & 15 & I & 1.053 & 3.861 & -6 & 7 & \multirow{2}{*}{-0.955} & \multirow{2}{*}{0.347} \\
\hline & 15 & $\mathrm{II}_{1}$ & 2.218 & 2.988 & -5 & 7 & & \\
\hline \multirow{2}{*}{ Ricketts Ls } & 15 & I & -5.953 & 3.559 & -12 & 0.5 & \multirow{2}{*}{1.627} & \multirow{2}{*}{0.105} \\
\hline & 15 & $\mathrm{II}_{1}$ & -3.875 & 3.471 & -8 & 0 & & \\
\hline \multirow{2}{*}{ Ricketts Li } & 15 & I & -3.140 & 2.735 & -9 & 1 & \multirow{2}{*}{0.458} & \multirow{2}{*}{0.650} \\
\hline & 15 & $\mathrm{II}_{1}$ & -2.675 & 3.575 & -4 & 1 & & \\
\hline \multirow{2}{*}{ Burstone Ls } & 15 & I & 3.890 & 2.491 & -2 & 9 & \multirow{2}{*}{-1.779} & \multirow{2}{*}{0.085} \\
\hline & 15 & $\mathrm{II}_{1}$ & 4.685 & 3.181 & 0 & 13 & & \\
\hline \multirow{2}{*}{ Burstone Li } & 15 & I & 3.218 & 2.309 & -2.5 & 8 & \multirow{2}{*}{-0.843} & \multirow{2}{*}{0.406} \\
\hline & 15 & $\mathrm{II}_{1}$ & 4.125 & 3.626 & -2 & 10 & & \\
\hline \multirow{2}{*}{ Sushner Ls } & 15 & I & 9.375 & 4.209 & 1 & 20 & \multirow{2}{*}{-3.376} & \multirow{2}{*}{$0.020^{*}$} \\
\hline & 15 & $\mathrm{II}_{1}$ & 15.012 & 5.186 & 8 & 23.7 & & \\
\hline \multirow{2}{*}{ Sushner Li } & 15 & I & 7.468 & 2.969 & 0 & 12.5 & \multirow{2}{*}{-2.111} & \multirow{2}{*}{$0.043^{*}$} \\
\hline & 15 & $\mathrm{II}_{1}$ & 10.375 & 4.638 & 2.5 & 7 & & \\
\hline \multirow{2}{*}{ Holdaway Li } & 15 & I & 1.333 & 1.588 & -2.5 & 14 & \multirow{2}{*}{1.038} & \multirow{2}{*}{0.308} \\
\hline & 15 & $\mathrm{II}_{1}$ & 0.500 & 2.674 & -5 & 4 & & \\
\hline \multirow{2}{*}{$\mathbf{H}^{\circ}$} & 15 & I & 11.800 & 3.320 & 0 & 19 & \multirow{2}{*}{-4.191} & \multirow{2}{*}{$0.000^{*}$} \\
\hline & 15 & $\mathrm{II}_{1}$ & 17.866 & 4.517 & 10 & 25 & & \\
\hline $\mathbf{Z}^{\circ}$ & 15 & I & 74.656 & 6.262 & 65 & 87 & 4.626 & $0.000 *$ \\
\hline & 15 & $\mathrm{II}_{1}$ & 60.875 & 10.136 & 47 & 76 & & \\
\hline NLA $^{\circ}$ & 15 & I & 101.533 & 11.945 & 83 & 122 & -0.469 & 0.643 \\
\hline & 15 & $\mathrm{II}_{1}$ & 104.000 & 16.505 & 88 & 136 & & \\
\hline $\mathbf{L M A}^{\circ}$ & 15 & I & 119.366 & 30.762 & 108 & 137 & 1.870 & 0.070 \\
\hline & 15 & $\begin{array}{c}\mathrm{H}_{1} \\
\mathrm{I}\end{array}$ & $\begin{array}{l}100.133 \\
13.153\end{array}$ & $\begin{array}{c}23.026 \\
1548\end{array}$ & 62 & $\begin{array}{c}135 \\
15\end{array}$ & & \\
\hline ULT & 15 & $\mathrm{II}_{1}$ & 12.800 & 2.484 & 9.5 & 10 & 0.507 & 0.616 \\
\hline $\mathbf{I} \mathbf{T}$ & 15 & I & 16.000 & 1.463 & 11 & 19 & 03 & 0 คว०* \\
\hline LL1 & 15 & $\mathrm{II}_{1}$ & 17.733 & 2.520 & 15.5 & 21 & -2.303 & $0.029^{*}$ \\
\hline
\end{tabular}

No: number; SD: standard deviation; Min.: Minimum; Max.: Maximum. * Significant difference existed at $p \leq 0.05$.

The females showed significant differences in number of variables between Class I and Class II Division 1. In relation to $\mathrm{S}_{1}$ line, upper lip showed a more protruded position in Class II Division 1 fe- males. While in relation to $\mathrm{E}$ line, upper and lower lips showed significantly higher values in Class I, who showed a significantly larger $\mathrm{Z}$ angle and significantly smaller $\mathrm{H}$ angle (Table 4). 
Table (4): Descriptive statistics and comparison between Class I and Class $\mathrm{II}_{1}$ females.

\begin{tabular}{|c|c|c|c|c|c|c|c|c|}
\hline Variable & No. & Class & Mean & $\pm \mathbf{S D}$ & Min. & Max. & t-test & $p$-value \\
\hline \multirow{2}{*}{ Steiner Ls } & 15 & I & -0.541 & 1.761 & -5 & 1.75 & \multirow{2}{*}{-2.634} & \multirow{2}{*}{$0.013^{*}$} \\
\hline & 15 & $\mathrm{II}_{1}$ & 1.328 & 2.237 & -4 & 6 & & \\
\hline \multirow{2}{*}{ Steiner Li } & 15 & $\mathrm{I}$ & -0.109 & 1.855 & -3 & 3.75 & \multirow{2}{*}{-1.758} & \multirow[b]{2}{*}{0.089} \\
\hline & 15 & $\mathrm{II}_{1}$ & 1.140 & 2.156 & -3 & 5.5 & & \\
\hline \multirow{2}{*}{ Ricketts Ls } & 15 & I & -5.640 & 2.010 & -10 & 2 & \multirow{2}{*}{4.273} & \multirow{2}{*}{$0.000^{*}$} \\
\hline & 15 & $\mathrm{II}_{1}$ & -2.937 & 1.537 & -5 & 0 & & \\
\hline \multirow{2}{*}{ Ricketts Li } & 15 & I & -4.140 & 2.204 & -6 & 2.5 & \multirow{2}{*}{3.691} & \multirow{2}{*}{$0.001^{*}$} \\
\hline & 15 & $\mathrm{II}_{1}$ & -1.718 & 1.425 & -1 & 1 & & \\
\hline \multirow{2}{*}{ Burstone Ls } & 15 & I & 3.046 & 1.166 & 0.25 & 4.75 & \multirow{2}{*}{-0.245} & \multirow{2}{*}{0.063} \\
\hline & 15 & $\mathrm{II}_{1}$ & 3.093 & 2.237 & 2 & 10 & & \\
\hline \multirow{2}{*}{ Burstone Li } & 15 & I & 1.578 & 1.660 & -1 & 5 & \multirow{2}{*}{-0.631} & \multirow{2}{*}{0.053} \\
\hline & 15 & $\mathrm{II}_{1}$ & 3.031 & 2.132 & 1 & 8 & & \\
\hline \multirow{2}{*}{ Sushner Ls } & 15 & I & 8.890 & 3.815 & 0.25 & 14.5 & \multirow{2}{*}{-0.573} & \multirow{2}{*}{0.571} \\
\hline & 15 & $\mathrm{II}_{1}$ & 9.687 & 4.045 & 1 & 20 & & \\
\hline \multirow{2}{*}{ Sushner Li } & 15 & I & 7.000 & 3.145 & 2 & 13 & \multirow{2}{*}{-0.312} & \multirow{2}{*}{0.758} \\
\hline & 15 & $\mathrm{II}_{1}$ & 7.343 & 3.096 & 0 & 12.5 & & \\
\hline \multirow{2}{*}{$\begin{array}{c}\text { Holdaway } \\
\qquad \mathbf{L i}\end{array}$} & 15 & I & -0.133 & 1.726 & -3 & 2 & \multirow{2}{*}{-1.545} & \multirow{2}{*}{0.133} \\
\hline & 15 & $\mathrm{II}_{1}$ & 0.812 & 1.682 & -4 & 3 & & \\
\hline \multirow{2}{*}{$\mathbf{H}^{\circ}$} & 15 & I & 11.366 & 3.838 & 8.30 & 18 & \multirow{2}{*}{-4.819} & $0.000 *$ \\
\hline & 15 & $\mathrm{II}_{1}$ & 17.593 & 3.352 & 12 & 22 & & 0.000 \\
\hline $\mathbf{Z}^{\circ}$ & 15 & I & 76.656 & 6.467 & 66 & 89 & 5.838 & $0.000 *$ \\
\hline & 15 & $\mathrm{II}_{1}$ & 62.406 & 7.314 & 47 & 73.5 & & \\
\hline NLA $^{\circ}$ & 15 & I & 110.90 & 10.461 & 90 & 124 & 1.523 & 0.139 \\
\hline 1VE & 15 & $\mathrm{II}_{1}$ & 104.562 & 12.527 & 75 & 127 & 1.020 & 0.10 \\
\hline $\mathbf{L M A}^{\circ}$ & 15 & I & 126.633 & 13.693 & 89 & 143 & 2.617 & 0.140 \\
\hline & 15 & $\mathrm{II}_{1}$ & 109.375 & 21.810 & 60 & 140 & 2.017 & 0.170 \\
\hline ULT & 15 & I & 12.766 & 2.757 & 9.5 & 16.5 & 0.616 & 0.542 \\
\hline & 15 & $\mathrm{II}_{1}$ & 12.031 & 3.770 & 8 & 19 & .078 & \\
\hline LLT & 15 & 1 & 15.133 & 2.655 & 11 & 20.5 & -1.885 & 0.070 \\
\hline & 15 & $\Pi_{1}$ & 17.000 & 2.846 & 15.5 & 20 & & \\
\hline
\end{tabular}

No: number; SD: standard deviation; Min.: Minimum; Max.: Maximum. * Significant difference existed at $p \leq 0.05$.

\section{DISCUSSION}

The individual variation in soft tissue thickness and the effect of the underlying skeleton demands careful attention in assessment. Different methods were used for analyzing the lip position and the thickness of the lips was also measured in order to get an approach for a more clear vision of the effect of gender and skeletal base differences on the lips which are fundamental for facial harmony. Also, the evaluation of success of orthodontic treatment will be affected by soft tissues as well as hard tissues. The reference lines that do not involve the tip of the nose are more preferable by many authors as they overcome the effect of the size of the nose. A significant difference was seen between
Class I and Class II Division 1 in both males and females in $\mathrm{H}$ angle and this is attributed to the increased facial convexity in Class II Division 1 subjects and according to Holdaway ${ }^{(20)} \mathrm{H}$ angle increases with the increase of facial convexity and the increase of ANB. On the other hand, no significant differences were seen between Class I males and females in $\mathrm{H}$ angle. This comes in agreement with Bascifitci et $a l .{ }^{(17)}$

Lower lip to $\mathrm{H}$ line showed a significant difference between Class I males and females. This disagrees with some authors' findings. ${ }^{(17,20,24)}$ Upper lip thickness showed no significant differences between males and females which disagrees with other findings. ${ }^{(21-24)}$ This could be attribut- 
ed to ethnic variation.

A significantly higher upper lip to $S_{1}$ line which was noticed in Class I males compared with females may reflect the effect of gender. This effect could also contribute to the significantly higher value of upper and lower lips to $\mathrm{S}_{2}$ line, while the underlying skeleton might be involved as the cause of the same results seen in Class I and Class II Division 1 females with the highest value for Class II Division 1. The backward position of the mandible which was reported by many authors to be the most important cause of Class II Division 1 could result in the backward inclination of $S_{2}$ line and lead to this finding.

The $\mathrm{Z}$ angle showed a significantly higher value in Class I in both males and females when compared with Class II Division 1 . This could be attributed to the backward and downward rotation of the mandible in Class II Division 1 subjects, while the significantly higher lower lip thickness in Class II Division 1 subjects could be related to the compensatory growth.

The significantly higher negative value seen in upper and lower lips position in relation to E line in Class I females compared with Class II Division 1 females may support the criticism of some authors towards the reference lines that involve the tip of the nose since it would not overcome the effect of the size of the nose and might give confusing results.

Upper lip thickness and lower lip thickness showed no significant differences between Class I males and females and this disagrees with the finding of Bascifisti et al. ${ }^{(17)}$ who found a significantly higher upper lip thickness in males, and Kalha et al. ${ }^{(25)}$ who reported a significantly higher upper and lower lip thickness in males.

The NLA and LMA demonstrated a very considerable dispersion around the mean values in males and females in both classes. This high standard deviation proposes a high variation in these two angles among the samples in both genders and both classes. When compared to males of Class I, females showed a significantly higher values of NLA which agrees with the finding of Kalha et al., ${ }^{(25)}$ who found a significantly higher NLA in females.

\section{CONCLUSIONS}

Some of the variables were not affected neither by gender nor by the skeletal base while others showed statistically significant differences following gender or skeletal class or both. However, the effect of skeletal base difference was more obvious and high number of significant differences were seen between the two Classes.

In Class I normal occlusion most of the variables showed no significant differences except with upper lip to $S_{1}$ line and $\mathrm{L}_{\mathrm{i}}$ to $\mathrm{H}$ with the highest value for the males while females showed a significantly higher NLA. While in Class II Division 1 males showed a significantly higher value than females of upper and lower lip to $\mathrm{S}_{2}$ line. Class II Division 1 males had significantly higher value of upper and lower lips in relation to $S_{2}$ line, significantly smaller $\mathrm{Z}$ angle and larger $\mathrm{H}$ angle, and larger lower lip thickness when compared to Class I males.

In comparison to Class I females, Class II Division 1 females had a significantly larger upper lip to $S_{1}$ line, smaller upper and lower lips to $\mathrm{E}$ line and significantly smaller $\mathrm{Z}$ and larger $\mathrm{H}$ angles.

\section{REFERENCES}

1. Bishara SE, Jacobsen JR, Hession TJ, Treder JE. Soft tissue profile change from 5 to 45 years of age. Am J Orthod Dentofacial Orthop. 1998; 114: 698-706.

2. Bishara SE, Firnandez AG. Cephalometric comparisons of the dentofacial relationships of two adolescent population from Iowa and Northern Mexico. Am J Orthod. 1985; 88: 314-322.

3. Hashim HA, Al-Barakati SF. Cephalometric soft tissue profile analysis between 2 different ethnic groups: A comparative study. J Contemp Dent Prac. 2003; 4(2): 1-9.

4. Wisth PJ, Thunbold K. Orthodontic Diagnosis and Treatment Planning. Bergen. 1985.

5. Hack GA, Otterloo JJ, Nanda R. Long term stability and prediction of soft tissue changes after Le Fort 1 surgery. Am J Orthod Dentofacial Orthop. 1993; 104: 544.

6. McNamara JAJr, Brust EW, Riolo ML. Soft tissue evaluation of individuals with an ideal occlusion and well balanced face. 
In: McNamara JAJr (ed). Esthetic and Treatment of Facial Form Monograph 28, Craniofacial Growth Series. Ann Arbor, Mich. Center for Human Growth and Development. The University of Michigan. 1992; Pp: 115-146.

7. Bass NM. Measurement of profile angle and the esthetic analysis of facial profile. $J$ Orthod. 2003; 30(1): 3-9.

8. Ferrario VF, Sforza C, Poggio CE, Schmitz JH. Three dimensional study of growth and development of the nose. Cleft Palate Craniofac J. 1997; 34: 309-317.

9. Fernandez RP, Smyth CE, Suarez QD, Suarez CM. Angular photogrammetric analysis of soft tissue facial profile. Eur $J$ Orthod. 2003; 25: 393-399.

10. Matoula S, Pancher ZH. Skeletofacial morphology of attractive and non attractive faces. Angle Orthod. 2006; 76: 204210.

11. Vander G, Oosterveld P, Vanheck G, Kuijpers J. Smile attractiveness. Angle Orthod. 2007; 77: 759-765.

12. Al-Taki A, Oguz F, Abuhijleh E. Facial soft tissue value in Persian adults with normal occlusion and well-balanced faces. Angle Orthod. 2009; 97(3): 491-494.

13. Keim RG. Achieving facial harmony through orthodontics. Calif Dent Assoc J. 2002; Nov.

14. Hashim HA. A cephalometric study of soft tissue relationship among Saudi female dental students. Saudi Dent J. 2003; 15(1): 41-44.

15. Sforza C, Laino A, D'Alessio R, Crandi G, Tartaglia GM, Ferrario VF. Soft tissue facial characteristics of attractive and normal adolescent boys and girls. Angle Orthod. 2007; 78(5): 779-807.

16. Saglum AMS, Gazilerili U. Analysis of Holdaway soft-tissuemeasurements in children between 9 and 12 years of age.
Eur J Orthod. 2001; 23: 287-294.

17. Basciftci FA, Uysal T, Buyukerkmen A. Determination of Holdaway soft tissue norms in Anatolian Turkish adults. Am J Orthod Dentofacial Orthop. 2003; 123: 395-400.

18. Hwang HS, Kim VS, McNamara JA. Ethnic differences in the soft tissue profile of Corean and European-American adults with normal occlusions and well-balanced faces. Angle Orthod. 2001; 72(1): 72-80.

19. Scavone HJ, Silva WZ, Carottimm V, Nahas CR. Soft tissue profile in White Brazilian adults with normal occlusions and well balanced faces. Angle Orthod. 2008; 78(1): 58-62.

20. Holdaway RA. A soft tissue cephalometric analysis and its use in orthodontic treatment planning. Part I. Am J Orthod. 1983; 84(1): 1-28.

21. Hasund A, Wisth PJ, Boe DE, Der H winkel in der kiefer-orthopadischen diagnostic. Fortschr Kieferortho D. 1980; 41: 40-46.

22. Erbay EF, Canikliglu CM, Erbay SK. Soft tissue profile in Anatolian Turkish adults: Part I. Evaluation of horizontal lip position using different soft tissue analyses. Am J Orthod Dentofacial Orthop. 2002; 121(1): 57-64.

23. Kaba LB, Pogrel MA, Perrott DH. Complications in Oral and Maxillofacial Surgery. $1^{\text {st }}$ ed. WB Saunders Co. Philadelphia. 1997; Pp: 56-60.

24. Abdul-Gadi MY, Al-Dawoody AD, Agha NF. Evaluation of Holdaway soft tissue analysis for Iraqi adults with Class I normal occlusion. Al-Rafidain Dent J. 2008; 8(2): 231-237.

25. Kalha AS, Latif A, Govardhan SN. Soft tissue cephalometric norms in a South Indian ethnic population. Am J Orthod Dentofacial Orthop. 2008; 133: 876-881. 